\title{
Effect of Organic Inputs on Growth and Flowering Attributes of Chrysanthemum cv. Snowball
}

\author{
Supriya Bordoloi* and Madhumita Choudhury Talukdar \\ Department of Horticulture, College of Agriculture, Assam Agricultural University, \\ Jorhat -785010, India \\ *Corresponding author
}

\begin{tabular}{|l|}
\hline Ke y w or d s \\
Height, Maximum \\
flower stalk length, \\
Size of flower, \\
Stem thickness \\
\hline Article Info \\
\hline Accepted: \\
17 November 2019 \\
Available Online: \\
10 December 2019 \\
\hline \hline
\end{tabular}

\section{A B S T R A C T}

An investigation was conducted during 2017-2018, to study the effect of organic inputs on vegetative and floral attributes of chrysanthemum cv. Snowball. The treatments comprising of $\mathrm{T}_{1}$ :Recommended dose of NPK@30:30:30 gm ${ }^{-2}+\mathrm{FYM}(4 \mathrm{~kg}$ $\left.\mathrm{m}^{-2}\right) ; \mathrm{T}_{2}$ : Rock Phosphate + Microbial Consortium; T3: $\mathrm{T}_{2}+$ Vermicompost $\left(2.5 \mathrm{tha}^{-1}\right)$; T4: $\mathrm{T}_{2}+$ Vermicompost $\left(5 \mathrm{tha}^{-1}\right) ; \mathrm{T}_{5}: \mathrm{T}_{2}+$ Compost $\left(2.5 \mathrm{t} \mathrm{ha}^{-1}\right) ; \mathrm{T}_{6}: \mathrm{T}_{2}+$ Compost $(5 \mathrm{t}$ $\left.\mathrm{ha}^{-1}\right) ; \mathrm{T}_{7}$ : Enriched compost $\left(2.5 \mathrm{tha}^{-1}\right)$ and $\mathrm{T}_{8}$ : Enriched compost $\left(5 \mathrm{tha}^{-1}\right)$. Among the treatments applied maximum height $(112.33 \mathrm{~cm})$, number of leaves $(59.67)$, leaf area $\left(88.00 \mathrm{~cm}^{2}\right)$, stem thickness $(1.33 \mathrm{~cm})$ were recorded in Rock Phosphate + Microbial Consortium+ Vermicompost $\left(5 \mathrm{t} \mathrm{ha}^{-1}\right)$ at all stages of plant growth. With respect to flowering, application of Rock Phosphate + Microbial Consortium+ Vermicompost (5t $\mathrm{ha}^{-1}$ ) was found best as it resulted in bud visibility in minimum days (48.33days), days to half bloom (82.00days), days to full bloom (87.67 days), maximum flower stalk length $(33.67 \mathrm{~cm})$, size of flower $(17.33 \mathrm{~cm})$ and weight of flower $(64.78 \mathrm{~g})$. Maximum duration of flowering (25.74days), self-life (18.67 days) and vase life(17.33days).Thus, it can be concluded from the findings that application of Rock Phosphate + Microbial Consortium+ Vermicompost $\left(5 \mathrm{tha}^{-1}\right)$ can be recommended for commercial cultivation of chrysanthemum cv. Snowball.

\section{Introduction}

Chrysanthemum occupies a prominent place in the national and international florist trade. It is next only to rose in importance in the international flower market. It is mainly grown for cut flower and loose flower for making garlands, veniand bracelets as well as for worshipping. Increased flower production, quality of flowers and perfection in the form of plants are the important objectives to be reckoned in commercial flower production. By using inorganic fertilizers, one can get higher yield but indiscriminate use of chemical fertilizers has adverse and ill effects on the soil structure, environment, flora and fauna. Recently, there is fall in mineral fertilizers consumption due to unprecedented hike in 
price of fertilizers and also soil and water pollution has aggravated the problem of soil health (Bhatia and Gupta, 2007). Chrysanthemum is a heavy feeder of nutrients specially nitrogen and phosphorus (Nalawadi, 1982). At present, these nutrients are supplied through chemical fertilizers. The chemical fertilizers play a key role by contributing 50$60 \%$ increase in productivity (Sindhu et al., 2010), but continuous use of chemical fertilizers not only adversely affects soil health and environment but also reduces productivity of crops. This situation emphasizes the need for developing alternate production systems that are friendlier to the environment and is more judicious in managing soil health. The increasing costs of fertilizers prevent their use by poor farmers (Adhikaryand Gantayet, 2012). Therefore, nowadays attention is shifted towards the alternate sources i.e., organic manures and bio inoculants. The role of organic manures and biofertilizers to make the soil healthy as well as make unavailable form of soil nutrients to available form by enhancing mineralization and solubilisation process. In soil by adding organic manures and microbial agents make easy uptake of nutrients when crop required comparing to chemical fertilizers (Vanilarasu and Balakrishnamurthy, 2014).

Biofertilizers or more appropriately called microbial inoculants are the preparations containing live or latent cells of efficient strains of microorganisms. These biofertilizers are a cost effective renewable energy source and plays a crucial role in reducing the inorganic fertilizer application and at the same time increasing the quality and yield of flowers besides maintaining soil fertility. These may be biological nitrogen fixers, P-solubilising, mineralization of nitrogen and transformation of several elements like sulphur and iron into available forms. Biofertilizers are cost effective and renewable source of plant nutrients to supplement chemical fertilizers (Borasteet al., 2009). Use of biofertilizers reduces per unit consumption of inorganic fertilizers and increase the quality and quantity of flower (Syamal et al., 2006). The role of organic manures and biofertilizers to make the soil healthy as well as make unavailable form of soil nutrients to available form by enhancing mineralization and solubilization process. In soil by adding organic manures and microbial agents make easy uptake of nutrients when crop required comparing to chemical fertilizers (Vanilarasu and Balakrishnamurthy, 2014). The use of manures as an organic source occupy an important place as they provide a scope for reduction in use of costly chemical fertilizers which can pollute soil in long term use (Sharma, 2005).Recently customized consortia of such bio-fertilizer organisms, better adapted to local climatic conditions have also been developed and are available commercially. Efficiency of such microbial formulations is much higher under no-chemical use situations, therefore application of such inputs need to be ensured under all cropping situations (Sateesh and Sivasakthivelan, 2013).

Modern and intensive agriculture calls for a heavy dependency on fertilizers and chemicals, besides neglecting the traditional good practices. In many areas, the overall health and productivity of the soil have declined to such an extent, that one cannot sustain profitable farming any more. Even the high yielding varieties of crops can perform to their potential, only if they are grown in productive soils. However, very little information is available until now with regard to use of these biofertilizers in floricultural crops especially in chrysanthemum. Keeping in view the importance of organic inputs, the present investigation was undertaken to find out the effect of organic inputs on vegetative and flowering parameters of chrysanthemum cv. Snowball. 


\section{Materials and Methods}

The present investigation was conducted during 2017-18 at the Experimental Farm, Department of Horticulture, Assam Agricultural University, Jorhat. The experiment was laid out in Randomized Block Design (RBD) with three replications. There were eight treatments which were applied as $\mathrm{T}_{1}$ : Recommended dose of NPK@30:30:30 $\mathrm{gm}^{-2}+\mathrm{FYM}\left(4 \mathrm{~kg} \mathrm{~m}^{-2}\right) ; \mathrm{T}_{2}$ : Rock Phosphate + Microbial Consortium; T3: $\mathrm{T}_{2}+$ Vermicompost (2.5 $\left.\mathrm{t} \mathrm{ha}^{-1}\right)$; T4: $\mathrm{T}_{2}+$ Vermicompost $\left(5 \mathrm{t} \mathrm{ha}^{-1}\right)$; $\mathrm{T}_{5}: \mathrm{T}_{2}+$ Compost $\left(2.5 \mathrm{t} \mathrm{ha}^{-1}\right) ; \mathrm{T}_{6}: \mathrm{T}_{2}+$ Compost $\left(5 \mathrm{t} \mathrm{ha}^{-1}\right) ; \mathrm{T}_{7}$ : Enriched compost $\left(2.5 \mathrm{tha}^{-1}\right)$ and $\mathrm{T}_{8}$ : Enriched compost $\left(5 \mathrm{t} \mathrm{ha} \mathrm{ha}^{-1}\right)$. Microbial consortium slurry was prepared with water and the rootdip treatment of seedlings was done an hour before transplanting. Consortium used in the experiment was the mixture of Azotobacter, Azospirillum, Phosphate solubilising bacteria and Rhizobium. Vermicompost, compost and enriched compost were applied during the land preparation. Microbial consortium, Vermicompost, Compost and Enriched Compost used in the experiment was procured from Assam Agricultural University, Jorhat, Assam. One month old seedlings were transplanted at a spacing of $30 \times 20 \mathrm{~cm}^{2}$ in the experimental plots.

\section{Results and Discussion}

Data pertaining to application of organic inputs on vegetative and floral attributes of chrysanthemum cv. Snowball are presented in Table 1-3. Perusal of data in Table 1 clearly showed that various plant growth parameters were significantly influenced by the various treatments. Application of Rock Phosphate + Microbial Consortium+Vermicompost (5t $\left.\mathrm{ha}^{-1}\right)$ i.e. $\mathrm{T}_{4}$ resulted in maximum plant height $(112.33 \mathrm{~cm})$, leaf number $(59.67)$, leaf area $\left(88.00 \mathrm{~cm}^{2}\right)$, intermodal length $(5.33 \mathrm{~cm})$, stem thickness (1.33) and stalk length $(33.67 \mathrm{~cm})$.
However, appreciable response of Enriched compost compost was also observed and it was found that treatment $\mathrm{T}_{7}$ i.e., Enriched compost $(2.5 \mathrm{t} / \mathrm{ha})$ excelled all other treatments except $\mathrm{T}_{4}$ for various vegetative attributes under study (Table 1). Increase in height might be due to the application of vermicompost, which supplies macronutrients, enzymes, and growth hormones and provides micronutrients such as $\mathrm{Zn}, \mathrm{Fe}, \mathrm{Cu}, \mathrm{Mn}$ in an optimum level. Similar findings were reported by Srivastava et al., (2014) in Tuberose. Fe and $\mathrm{Zn}$ might have enhanced the microflora and enzymatic activity which might have augmented plant growth. The positive effect of vermicompost on plant growth has been reported by Nethra et al., (1999) in china aster and Gangadharan and Gopinath (2000) in gladiolus. Any of these effects would have led to increase in plant growth. The application of organic manures increases the water holding capacity of soil and the increase in moisture content in soil might enhanced the degree of metabolic activities at the growing apex enabling higher production of leaves. The increase in plant height and number of leaves per plant with application of organic inputs are in conformity with the findings of Gayathri et al., (2004) in statice.

Minimum days taken to colour break stage were found in $\mathrm{T}_{4}$ i.e., Rock Phosphate + Microbial Consortium+ Vermicompost (5t $\mathrm{ha}^{-1}$ ) in 75.33 days which is followed by $\mathrm{T}_{7}$ (75.67 days). However the maximum days taken were observed in $\mathrm{T}_{2}$ i.e., Rock Phosphate + Microbial Consortium in 85.33 days. Minimum days taken to $1^{\text {st }}$ bud visibility were found in $\mathrm{T}_{4}$ (48days) closely followed by $\mathrm{T}_{7}$ i.e., Enriched compost (2.5t/ha) in 51 days. However this trait was delayed most in $T_{2}(61$ days). As far as number of days taken to half bloom and full bloom is concerned, it varied significantly with respect to different treatments used. Number of days taken to half bloom ranged from 82 to 104 days with 
minimum in $\mathrm{T}_{4}$ i.e., Rock Phosphate + Microbial Consortium+ Vermicompost (5t $\mathrm{ha}^{-1}$ ) and maximum in $\mathrm{T}_{2}$ i.e., Rock Phosphate + Microbial Consortium (Table 2). Earliness in days taken to $50 \%$ flowering, days taken to attain the colour break stage and days taken to full bloom might be due to increased uptake of nutrients by the plants which resulted in more plant height, number of branches, plant spread, leaf area and dry matter production. This might have led to the early completion of the vegetative growth and early transformation of vegetative to reproductive phase. These results are in line with the results reported by Gayithri et al., (2004) in statice, Smita et al., (2006) in china aster. This increase might also be due to the presence of gibberellins in vermicompost, which are associated with the regulation of flowering. These findings are in corroboration with the work of Vetal et al., (2003) in lilium, Bhalla et al., (2007) in Carnation

With regards to stalk length, it was observed that application of Rock Phosphate + Microbial Consortium+ Vermicompost (5t $\left.\mathrm{ha}^{-1}\right)$ gave maximum stalk length $(33.67 \mathrm{~cm})$ and minimum (22.00) in Rock Phosphate + Microbial Consortium. The increase in stalk length might be due to better nutrient uptake, increased leaf area (Table 1) which might have resulted in higher photosynthetic efficiency, source-sink relationship, besides excellent physiological and biochemical activities due to the presence of Azospirillum and PSB. This may also be attributed to vermicompost as it might have helped in better supply of macro and micro nutrients, enzymes and growth hormones. Similar results were revealed by Prabhat Kumar et al., (2003) in china aster, Godse et al., (2006) in gladiolus. The diameter of the flower which represents the size of the flower is an important aspect governing the quality of the chrysanthemum flower was maximum $(17.33 \mathrm{~cm})$ with application of Rock Phosphate + Microbial Consortium+ Vermicompost (5t $\left.\mathrm{ha}^{-1}\right)$. The increase in flower size might be due to the better vegetative growth encouraged by increase in nutrient status of the soil. Addition of organic manures supplements a wide range of nutrients to the plants that help in the maintenance of healthy status and increase in various flower attributes. Addition of organic manures supplements a wide range of nutrients to the plants that help in the maintenance of healthy status and increase in various flower attributes. Similar findings have been reported by Chaitra and Patil (2007) in China aster.

Table.1 Effect of organic inputs on vegetative attributes of chrysanthemum cv. Snowball

\begin{tabular}{|c|c|c|c|c|c|}
\hline Treatment & $\begin{array}{c}\text { Plant } \\
\text { height } \\
(\mathbf{c m})\end{array}$ & $\begin{array}{c}\text { Leaf } \\
\text { number }\end{array}$ & $\begin{array}{c}\text { Leaf area } \\
\left(\mathbf{c m}^{-2}\right)\end{array}$ & $\begin{array}{c}\text { Internodal } \\
\text { length } \\
(\mathbf{c m})\end{array}$ & $\begin{array}{c}\text { Stem thickness } \\
(\mathbf{c m})\end{array}$ \\
\hline $\mathrm{T}_{1}$ & 98.670 & 50.67 & 81.53 & 4.00 & $\mathbf{0 . 6 0}$ \\
\hline $\mathrm{T}_{2}$ & 90.67 & 45.78 & 42.66 & 4.33 & $\mathbf{0 . 5 0}$ \\
\hline $\mathrm{T}_{3}$ & 106.33 & 55.67 & 78.52 & 5.00 & $\mathbf{0 . 9 6}$ \\
\hline $\mathrm{T}_{4}$ & 112.33 & 59.67 & 88.00 & 5.33 & $\mathbf{1 . 3 3}$ \\
\hline $\mathrm{T}_{5}$ & 92.67 & 41.33 & 66.16 & 4.33 & $\mathbf{0 . 6 6}$ \\
\hline $\mathrm{T}_{6}$ & 94.00 & 37.00 & 64.33 & 4.16 & $\mathbf{0 . 6 0}$ \\
\hline $\mathrm{T}_{7}$ & 109.33 & 53.33 & 82.50 & 5.16 & $\mathbf{0 . 7 3}$ \\
\hline $\mathrm{T}_{8}$ & 104.67 & 51.67 & 72.33 & 4.66 & $\mathbf{0 . 7 0}$ \\
\hline $\mathrm{CD}(0.05)$ & 1.64 & 1.40 & 1.54 & $0 \mathrm{NS}$ & $\mathbf{0 . 3 7}$ \\
\hline
\end{tabular}


Table.2 Effect of organic inputs on flowering attributes of chrysanthemum cv. Snowball

\begin{tabular}{|c|c|c|c|c|c|c|c|c|}
\hline Treatment & $\begin{array}{c}\text { Days } \\
\text { Taken To } \\
\text { Bud } \\
\text { Visibility }\end{array}$ & $\begin{array}{c}\text { Colour } \\
\text { Break } \\
\text { Stage } \\
\text { (days) }\end{array}$ & $\begin{array}{c}\text { Days } \\
\text { Taken To } \\
\text { Half Bloom }\end{array}$ & $\begin{array}{c}\text { Days } \\
\text { Taken To } \\
\text { Full Bloom }\end{array}$ & $\begin{array}{c}\text { Stalk } \\
\text { length } \\
(\mathbf{c m})\end{array}$ & $\begin{array}{c}\text { Size of } \\
\text { flower }(\mathbf{c m})\end{array}$ & $\begin{array}{c}\text { Flower number/ } \\
\text { plant }\end{array}$ & $\begin{array}{c}\text { Fresh } \\
\text { Weight }(\mathbf{g})\end{array}$ \\
\hline $\mathrm{T}_{1}$ & 55.33 & 77.67 & 86.00 & 94.67 & 26.33 & 13.67 & 4.67 & $\mathbf{3 8 . 3 3}$ \\
\hline $\mathrm{T}_{2}$ & 61.67 & 85.33 & 104.33 & 108.00 & 22.00 & 13.33 & 3.67 & $\mathbf{3 1 . 0 0}$ \\
\hline $\mathrm{T}_{3}$ & 53.33 & 76.67 & 84.67 & 90.00 & 32.33 & 16.00 & 4.33 & $\mathbf{5 4 . 2 3}$ \\
\hline $\mathrm{T}_{4}$ & 48.33 & 75.33 & 82.00 & 87.67 & 33.67 & 17.33 & $\mathbf{6 4}$ \\
\hline $\mathrm{T}_{5}$ & 55.00 & 80.67 & 90.00 & 95.67 & 25.67 & 14.67 & 4.00 & $\mathbf{3 4 . 3 3}$ \\
\hline $\mathrm{T}_{6}$ & 52.67 & 78.33 & 94.00 & 96.67 & 31.33 & 15.33 & 4.00 & $\mathbf{3 5 . 0 0}$ \\
\hline $\mathrm{T}_{7}$ & 51.33 & 75.67 & 83.67 & 88.67 & 33.00 & 16.67 & 5.00 & $\mathbf{5 6 . 3 3}$ \\
\hline $\mathrm{T}_{8}$ & 52.33 & 76.33 & 86.00 & 91.67 & 30.33 & 15.67 & 4.33 & $\mathbf{4 8 . 7 0}$ \\
\hline $\mathrm{CD}(0.05)$ & 1.36 & 1.06 & 1.58 & 1.60 & 1.62 & 1.25 & $\mathbf{N S}$ \\
\hline
\end{tabular}

Table.3 Effect of organic inputs on duration of flowering, self-life and vase life of chrysanthemum cv. Snowball

\begin{tabular}{|c|c|c|c|}
\hline Treatment & $\begin{array}{c}\text { Duration Of Flowering From First } \\
\text { Bloom To Last Bloom (Days) }\end{array}$ & Self-Life (Days) & Vase Life (Days) \\
\hline $\mathrm{T}_{1}$ & 21.00 & 12.33 & $\mathbf{9 . 3 3}$ \\
\hline $\mathrm{T}_{2}$ & 24.41 & 13.67 & $\mathbf{1 1 . 3 3}$ \\
\hline $\mathrm{T}_{3}$ & 25.26 & 16.33 & $\mathbf{1 5 . 3 3}$ \\
\hline $\mathrm{T}_{4}$ & 25.74 & 18.67 & $\mathbf{1 7 . 3 3}$ \\
\hline $\mathrm{T}_{5}$ & 22.85 & 14.00 & $\mathbf{1 3 . 3 3}$ \\
\hline $\mathrm{T}_{6}$ & 23.80 & 15.67 & $\mathbf{1 2 . 0 0}$ \\
\hline $\mathrm{T}_{7}$ & 24.47 & 18.33 & $\mathbf{1 6 . 0 0}$ \\
\hline $\mathrm{T}_{8}$ & 23.33 & 17.33 & $\mathbf{1 4 . 6 7}$ \\
\hline $\mathrm{CD}(0.05)$ & 1.30 & 0.97 & $\mathbf{0 . 3 0}$ \\
\hline
\end{tabular}


Average weight of flower ranged from $31.00 \mathrm{~g}$ to $64.78 \mathrm{~g}$ with minimum in Rock Phosphate + Microbial Consortium and maximum in Rock Phosphate + Microbial Consortium+ Vermicompost $\left(5 \mathrm{t} \mathrm{ha} \mathrm{ha}^{-1}\right)$. Fresh weight increased due to biological fixation of nitrogen and phosphorus in root portion of plants resulting in absorption of more nutrients and its utilization. Moreover, Azospirillum has a role in nitrogen fixation and is also involved in the production of GA and cytokinin like substances which enhance the growth of plants. These findings are in accordance with the results of Rajesh et al., (2006) who reported that application of bio-fertilizers like Azospirillum, Phosphate solubilizing bacterium enhanced the flower fresh weight in carnation. In chrysanthemum cv. Snowball, size of the flower is an important criterion for cut flower production rather than number of flowers as in loose flowers.

Duration of flowering recorded from peak flowering up to the stage till plants remain presentable was found more with application of Rock Phosphate + Microbial Consortium+ Vermicompost $\left(5 \mathrm{tha}^{-1}\right)\left(\mathrm{T}_{4}\right)$. Similarly, flower longevity was also found maximum in the same treatment i.e., $\mathrm{T}_{4}$. Apart from this treatment, appreciable duration of flowering was also observed with the application of $\mathrm{T}_{3}$ and $\mathrm{T}_{7}$.

This variation could be attributed to the better vegetative growth of the cultivars with longer flowering duration and more number of flowers per plant during the entire period. The growth characters like more number of leaves per plant, greater leaf area, higher net assimilation rate, greater chlorophyll content resulted in production and accumulation of maximum photosynthates resulting in more progressive emergence of flowers per plant, which increases the blooming duration. These findings are in accordance with the results of Rajesh et al., (2006) in gerbera. Plants grown in control had minimum days taken to half of leaves and flowers showing wilting. Vermicompost is rich in humus, which contains essential plant nutrients and rich in vitamins, beneficial microorganism, antibiotics, enzymes, etc., which are available for long term nutritional needs of plant growth. FYM helps in improving soil health and it ensures proper aeration in soil and improves water holding capacity of soil. These findings are in conformity with the findings of Hemavathy in chrysanthemum, Haripriyaet al., in rose (Rosa centifolia) cv. Andhra Red. Application of organic manures influenced flower longevity due to the increased nutrient uptake by plant and greater development of water conducting tissues. Azospirillum releases cytokinins which might delay senescence of florets.

From these studies, it could be inferred that combination Rock Phosphate + Microbial Consortium+ Vermicompost $\left(5 \mathrm{t} \mathrm{ha}^{-1}\right)$ was found to be the best treatment combination for good growth and flowering attributes in chrysanthemum cv. Snowball

\section{References}

Adhikary, S. P. and Gantayet, P. K. (2012). Studies on the influence of organic fertilizers on the growth and some biochemical parameters of chilli (Capsicum annum L. Var). The Bioscan. 7(2): 255-258

Bhalla, R.; Shivakumar, M.H. and Jain, R. (2007). Effect of organic manures and biofertilizers on growth and flowering in' Standard carnation (Dianthus carypohyllus Linn.). J. Ornam. Hort. 10: 229-234.

Bhatia, S. and Gupta, Y. C. 2007. Studies on use of biofertilizer in carnation (Dianthus caryophyllus Linn.) flower production. J. Ornamental Horticulture. 10(2): 131-132 
Boraste, A., Vamsi, K. K., Jhadav, A., Khairnar, Y., Gupta, N., Patil, S. P. T., Gupta, G., Gupta, M., Mujapara, A. K. and Joshi, B. (2009). Bio-fertilizers: A novel tool for agriculture. International J. Microbiology Research. 1(2): 23-31

Chaitra, R. and Patil, V. S. 2007. Integrated Nutrient Management studies in China Aster (Callistephus chinensis Nees) cv. Kamini. Karnataka J. Agricultural Sciences. 20(3): 689-690.

Gayathri, H.N.; Jayaprasad, K.V. and Narayanaswamy, P. (2004). Response of biofertilizers and their combined application with different levels of inorganic fertilizers in statice (Limonium caspia). J. Ornam. Hort. 7: 70-74.

Godse, S. B.; Golliwar, V. J.; NehaChopdeBramhankar, K. S.; Kore M. S. (2006). Effect of organic manures and biofertilizers with reduced doses of inorganic fertilizers on growth, flowering, yield and quality of gladiolus. Journal of Soils and Crops16(2) 445-449.

Gopinath, K.A. and Mina, B.L. (2011).Effect of organic manures on agronomic and economic performance of garden pea (Pisum sativum) and on soil properties. Indian J. Agril. Sci. 81(3): 236-239.

Haripriya K., Senthilkumar S. and Sriramachandrasekharan M.V. (2004) Journal of Interacademicia, 8(2), 207210.

Hemavathy M. (1997) M.Sc. (Ag.)Thesis, College of Agriculture, University of Agricultural Sciences, Dharwad, Bangalore, Karnataka.

Nalawadi, U.G., (1982). Nutritional studies in some varieties of marigold (Tagetes erecta L.). Ph.D. Thesis submitted to the University of Agricultural Sciences, Dharwad.

Nethra, N.N.; Jayaprasad, K.V. and Kale, R.D.
(1999).China aster (Callistephus chinensis L., Ness) cultivation using vermicompost as organic amendment. Crop Res., Hissar17: 209-215.

PrabhatkumarRaghava S P S and Mishra R L 2003 Effect of biofertilizers on growth and yield of china aster. Journal of Ornamental Horticulture, 6(2):85-88

Rajesh, B.; Sandeep, D.; Dhiman, S. R. and Ritu, J. (2006). Effect of Biofertilizers and Biostimlants on Growth and Flowering in Standard Carnation (Dianthus caryophyllus Linn.).J. Ornam. Hort. 9: 282-284.

Sateesh, S and Sivasakthivelan, P. (2013). Studies on the Influence of bioinoculant consortium on chillies and its effect on soil health management. Intl. J. Chem. Tech. Res. 5(3): 1326-1328

Sharma, A. K. (2005). The living soil. In: Biofertilizers for Sustainable Agriculture, Agrobios, (India), Jodhpur: 1-19

Sindhu, S.S., Verma, N., Dua, S. and Chaudhary, D., (2010). Biofertilizer application for growth stimulation of horticultural crops. Haryana Journal of Horticultural Sciences, 39(1\&2): 48-70

Smita A Mogal Khiratkar S D Neha K Chopde Dalvi A M Ommala D Kuchanwar Khobragade Y R (2006). Effect of organic manures and biofertilizers with reduced doses of nitrogen on growth, yield and quality of china aster. Journal of Soils and Crops., 16(1):180-185.

Srivastava, R.; Preetham, S.P. and Chand, S. (2014). Effect of organic manures and biofertilizers on vegetative, floral and post-harvest attributes in tuberose (Polianthes tuberosa) var. Shringar. Asian J. Biol. Life Sci. 3: 6-9

Syamal, M. M., Dixit, S. K. and Kumar, S. 2006. Effect of bio-fertilizers on 
growth and yield in marigold. $J$. Ornamental Horticulture. 9(4): 304305

Vanilarasu, K. and Balakrishnamurthy, G. (2014). Influences of organic manures and amendments in soil physiochemical properties and their impact on growth, yield and nutrient uptake of banana. The Bioscan., 9(2): 525-529.

Vetal A.A., Dutt M. and Sonwae P.C. (2003) Crop Research, Hissar. 25(1), 78-82.

\section{How to cite this article:}

Supriya Bordoloi and Madhumita Choudhury Talukdar. 2019. Effect of Organic Inputs on Growth and Flowering Attributes of Chrysanthemum cv. Snowball. Int.J.Curr.Microbiol.App.Sci. 8(12): 2189-2196. doi: https://doi.org/10.20546/ijcmas.2019.812.260 